\title{
DEVELOPING SITE-SPECIFIC ALLOMETRIC EQUATIONS FOR ABOVE-GROUND BIOMASS ESTIMATION IN PEAT SWAMP FORESTS OF ROKAN HILIR DISTRICT, RIAU PROVINCE, INDONESIA
}

\author{
Nunung Puji Nugroho ${ }^{1 *}$ \\ Received: 7 November 2012, Accepted: 18 March 2014
}

\begin{abstract}
In forest biomass assessment studies, the selection or development of reliable allometric biomass equations is an essential step which determines largely the accuracy of the resulted biomass estimates. Unfortunately, only few studies on allometric biomass equations have been conducted for peat swamp forests and the results are usually not publicly accessible or well documented. Thus, the objective of this study was to develop sitespecific allometric equations for above-ground biomass (AGB) estimations in tropical peat swamp forests in Indonesia. These equations were developed based on 51 destructively sampled trees. The results indicated that the developed site-specific allometric equations have coefficient of determination $\left(\mathrm{R}^{2}\right)$ greater than $95 \%$. The $\mathrm{R}^{2}$ values ranged from $97.0 \%$ to $98.7 \%$, where the lowest $\mathrm{R}^{2}$ value resulted from the simplest model which used only $\mathrm{DBH}$ as a predictor. Model 5, which used DBH, $\mathrm{H}$ and $\varrho$ as predictive variables, provided best performance when estimating the AGB of the study area. Hence, as long as reliable data are available as input, Model 5 is recommended. The accuracy and applicability of the allometric equations for peat swamp forests could be improved further by adding more sampled trees from different tree species and/or with a wider DBH range. Considering the importance of wood density in the estimation of the AGB and the lack of this information for peat swamp forest tree species, research should be dedicated to analysing the wood density of the dominant tree species comprising the majority of the AGB density in the study area.
\end{abstract}

Keywords: Site-specific, allometric equation, above-ground biomass, peat swamp forest, Riau

\begin{abstract}
ABSTRAK
Dalam kajian-kajian penaksiran biomassa hutan, pemilihan atau pengembangan persamaan-persamaan alometrik biomassa yang dapat diandalkan merupakan langkah penting yang sangat menentukan ketepatan dari dugaan biomassa yang dihasilkan. Sayangnya, hanya sedikit kajian-kajian tentang persamaan alometrik biomassa yang dilakukan di hutan rawa gambut dan hasil-hasilnya biasanya tidak dapat diakses secara umum atau terdokumentasi dengan baik. Jadi, kajian ini bertujuan untuk mengembangkan persamaan-persamaan alometrik spesifik tapak untuk pendugaan biomassa atas permukaan di hutan rawa gambut di Indonesia. Persamaanpersamaan tersebut dikembangkan berdasarkan 51 pohon contoh yang ditebang. Hasil dari kajian ini menunjukkan bahwa persamaan-persamaan alometrik yang dikembangkan mempunyai koefisien determinasi lebih dari $95 \%$ dengan rentang nilai mulai dari 97,0\% sampai dengan 98,7\%. Dalam hal ini, koefisien determinasi yang paling rendah dihasilkan oleh persamaan alometrik yang paling sederhana dengan satu peubah, yaitu diameter setinggi dada (Model 1). Model 5 yang menggunakan tiga peubah (diameter setinggi dada, tinggi total dan kerapatan kayu) menghasilkan dugaan biomassa atas permukaan yang paling baik di wilayah kajian. Oleh karena itu, selama data peubah tersebut tersedia, maka Model 5 direkomendasikan dalam pendugaan biomassa atas permukaan di hutan rawa gambut. Ketepatan dan penerapan dari persamaan-persamaan alometrik ini dapat ditingkatkan dengan menambahkan pohon contoh dari jenis lain dan/atau dengan rentang diameter setinggi dada yang lebih besar. Mempertimbangkan pentingnya kerapatan kayu dalam pendugaan biomassa dan kurangnya informasi ini untuk jenis-jenis pohon di hutan rawa gambut, maka penelitian perlu dilakukan untuk menganalisis kerapatan kayu untuk jenis-jenis dominan yang menyumbang kerapatan biomassa terbesar pada wilayah kajian.
\end{abstract}

Kata kunci: Spesifik tapak, persamaan alometrik, biomassa atas permukaan, hutan rawa gambut, Riau

${ }^{1}$ Research Institute for Forestry Technology on Watershed Management, Jl. Jend. A. Yani Pabelan Kotak Pos 295, Surakarta, Central Java 57012 Indonesia

"Corresponding Author: np_nugroho04@yahoo.com 


\section{INTRODUCTION}

Accurate estimation of above- and belowground biomass (AGB and $\mathrm{BGB}$ ) in tropical peat swamp forest ecosystems is important to understand their roles in the global carbon cycle, particularly in relation to climate change. Reliable information on the biomass ("organic material both above-ground and below-ground, and both living and dead"(FAO, 2006, p.172), expressed as oven-dry ton or Megagramme (Mg) per ha) of forest ecosystem is also crucial for assessing forest structure and condition (Chave et al., 2003; Zianis, 2008; Návar, 2009), forest productivity (Clark et al., 2001; Zianis, $2008)$ and nutrients cycle and energy fixation (Zianis et al., 2005; Zianis, 2008). Biomass is also an indicator of site productivity (Návar, 2009), both in biological and economical terms (Cole and Ewel, 2006) and is important to support the implementation of sustainable forest management (Zianis et al., 2005; Labrecque et al., 2006; Lucas et al., 2006) and the conservation of biodiversity (Lucas et al., 2006).

Knowledge of the spatial distribution of and changes in the biomass has been required for some time but the need is becoming more urgent, particularly because of emerging mechanisms for mitigating greenhouse gases (GHGs), such as Reducing Emissions from Deforestation and forest Degradation (REDD) in developing countries (Gibbs et al., 2007; Sierra et al., 2007; Basuki et al., 2009; Goetz et al., 2010; Saatchi et al., 2011). To best quantify carbon dynamics, consecutive measurements of forest biomass (Chambers et al., 2001; Clark et al., 2001) and accumulation rates (Sierra et al., 2007; Návar, 2009; Wijaya et al., 2010; Banskota et al., 2011) are needed together with information on the extent and rate of forest disturbances associated with natural or anthropogenic land use changes and fire events (Brown et al., 1995; Sierra et al., 2007; Wijaya et al., 2010).

\footnotetext{
${ }^{2}$ In peat swamp forests, the AGB represents the second largest carbon pool after peat soil.
}

Many studies on forest biomass assessment are focused on AGB (e.g. Brown, 1997; Foody et al., 2001; Ketterings et al., 2001; Losi et al., 2003; Aboal et al., 2005; Segura and Kanninen, 2005; Saatchi et al., 2007; Basuki et al., 2009; Kenzo et al., 2009a) because it represents the largest carbon pool ${ }^{2}$ of forest vegetation and is directly impacted by deforestation and degradation (Gibbs et al., 2007). Field-based measurement is one of the methods for estimating the biomass of the forest ecosystems (Lu, 2006; Anaya et al., 2009). This method is commonly conducted by applying allometric biomass regression equations or simply allometric equations (Brown, 2002; Verwer and Meer, 2010). These are mathematical equations that relate easily-measured variables (e.g. diameter at breast height, base diameter and tree height) to attributes that are more difficult to assess (e.g. standing volume and biomass or leaf area) (Ketterings et al., 2001; Goetz et al., 2010).

Many allometric equations have been developed for tropical forests, with some being site-specific and developed from in situ harvesting of sampled trees of mixedspecies (e.g. Yamakura et al., 1986; Chambers et al., 2001; Ketterings et al., 2001; Segura and Kanninen, 2005; Jepsen, 2006; Basuki et al., 2009; Kenzo et al., 2009a; Kenzo et al., 2009b). Others (e.g. Brown et al., 1989; Brown, 1997; Zianis and Mencuccini, 2004; Chave et al., 2005; Pilli et al., 2006) are more generalized having been developed from trees sampled across a wider geographical range and as a function of forest type. Well-known and commonly used equations include that of Brown (1997), which was derived from sampled trees collected across the pan-tropical region, and Chave et al., (2005), which considered the differences between dry and wet forest types. These equations have used data from the Neotropics, Southeast Asia and Oceania, including Indonesia, but none of the sampled trees have been collected from peat swamp forests (Verwer and Meer, 2010). The use of allometric equations is advocated as direct field measurement, whilst it is more accurate (Lu, 2006), but it is also expensive, time 
consuming and labour intensive (Houghton, 2005).

Compared to other tropical forestecosystems, peat swamp forest is considered a unique and fragile ecosystem (Page et al., 1999; Rieley, 2007). It is characterized by its occurrence on peat soil with high-rainfall, high-temperature, waterlogged and acidified substrate conditions that lack oxygen (Wösten et al., 2006; Hirano et al., 2007; Jaenicke et al., 2008; Posa et al., 2011) where the decomposition rate of woody plant debris is slower than the accumulation rate of the materials (Maltby and Immirzi, 1993; Rieley and Page, 2005). This ecosystem is fragile because of the strong interdependency between hydrology, ecology and landscape morphology (Page et al., 1999) where a change in any of these components will alter and affect the balance of the ecosystem (Hooijer et al., 2009; Hooijer et al., 2010). As a consequence of this characteristic, peat swamp forest ecosystem has the potential to store huge amounts of carbon (Sorensen, 1993; Tawaraya et al., 2003; Jaenicke et al., 2008), especially as Soil Organic Matter (SOM) (Hirano et al., 2007).

Although peat swamp forest is a significant repository of carbon, disturbance can transform it to a large source of carbon emissions (Rieley and Page, 2005). However, there is a lack of information on the amount of the biomass stored within the peat swamp forest (Verwer and Meer, 2010). The majority of studies have focused mainly on the impacts of fire and subsequent recovery of the forest ecosystem, the amount of carbon in the peat soils, mycorrhizal activity, and biodiversity (Page et al., 2002; Tawaraya et al., 2003; Wahyunto et al., 2003; Wahyunto et al., 2004; Wahyunto et al., 2005; Hooijer et al., 2006; Wahyunto et al., 2006; Wösten et al., 2006; Jaenicke et al., 2008; Uryu et al., 2008; Wahyunto and Suryadiputra, 2008; Wösten et al., 2008; Wahyunto et al., 2010). Few studies have been conducted on the biomass of the peat swamp forests (e.g. Ludang and Jaya, 2007; Krisnawati and Imanuddin, 2011; Tan et al., 2011) and most have used the available generalized or pan-tropical allometric equations (e.g. Brown et al., 1989; Brown, 1997; Chave et al., 2005) instead of allometric equations specific to peat swamp forests and from Indonesia. Currently, site-specific allometric equations for peat swamp forest that are publicly available are limited (see Solichin et al., 2011; Krisnawati et al., 2012). Thus, the objective of this study was to develop site-specific allometric equations for $\mathrm{AGB}$ estimations for tropical peat swamp forests, with special reference to peat swamp forests in Rokan Hilir District, Riau Province.

\section{MATERIAL AND METHOD}

\section{A. Study Site}

This study was conducted at the selected logging blocks within the concession area

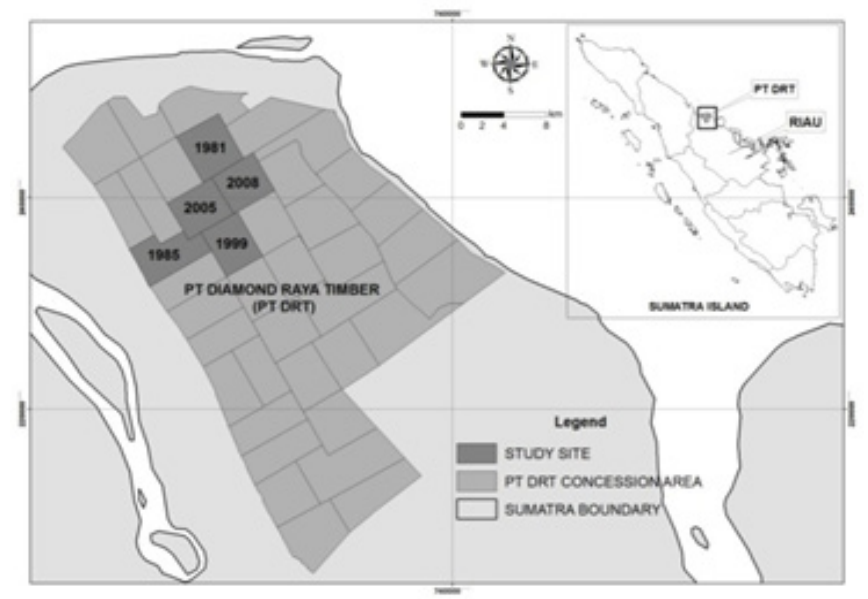

Figure 1. The selected study site within the forest concession area of PT. Diamond Raya Timber 
managed by PT. Diamond Raya Timber (PT. DRT) (Figure 1) in Rokan Hilir District, Riau Province, Indonesia $\left(100^{\circ} 48^{\prime}-101^{\circ} 13^{\prime} \mathrm{E}\right.$ and $1^{\circ} 49^{\prime}-2^{\circ} 18^{\prime} \mathrm{N}$ (Istomo, 2002). It is mainly covered by the lowland peat swamp forest with the dominant commercial species of balam (Palaquium obovatum (Griffith) Enql.), meranti batu (Shorea uliginosa Foxw.), ramin (Gonystylus bancanus (Miq.) Kurz.), and terentang (Camnosperma coriaceum (Jack.) Hallier f. ex v. Steenis). This forest is also the important habitat for the endangered species of the Sumatran tiger (Panthera tigris sumatrae).

The topography of the area is flat with the elevation ranges from $0-8 \mathrm{~m}$ a.s.l. (meter above sea level). In addition, the area is geologically dominated by peat dome along with alluvial and marine groups (Istomo, 2002). The dominant soil type is thick peat soil with a depth of more than $3 \mathrm{~m}$, while the minor ones are gley, alluvial and podzolic. Based on the Schmidt and Ferguson climate classification, the area is classified as A type with Q value of $10.1 \%$ (Istomo, 2002). The average monthly rainfall ranges from 51.3 to $301.6 \mathrm{~mm}$ where the highest is in November $(301.6 \mathrm{~mm})$ and the lowest is in March (51.3 mm). Furthermore, the mean annual temperature ranges from 25 to 27 ${ }^{\circ} \mathrm{C}$ and the relative humidity ranges from $79 \%$ to $90 \%$.

\section{B. Data Collection}

The data collection through destructive sampling was carried out from August to September 2008. A total of fifty one healthy ${ }^{3}$ trees comprising eleven species with the $\mathrm{DBH}$ ranging from 5.2 to $62.7 \mathrm{~cm}$ were felled (details are presented in Appendix 1). The sampled trees were mainly selected based on dominant tree species present in the study area according to the available data from the permanent sample plot (PSP). Out of the eleven tree species felled during the fieldwork, nine were associated with the dominant species. The DBH, which is the

\footnotetext{
${ }^{3}$ Healthy tree in this article is defined as a tree without broken top or infected by a disease.
}

diameter at $1.3 \mathrm{~m}$ above the ground or $30 \mathrm{~cm}$ above the buttress (FAO, 2004), was measured using a diameter tape before the tree was felled. The scientific name of the sample trees were verified using the database of the World Agroforestry Centre (CGIAR, 2008) and a previous study (Istomo, 2002).

After the tree was felled, the total tree height $(\mathrm{H})$ was measured using a 50-m measuring tape. Then, the sample tree was separated into four components: (1) leaves, (2) twigs (diameter < $3.2 \mathrm{~cm}$ ), (3) small branches (diameter between $6.4 \mathrm{~cm}$ and $3.2 \mathrm{~cm}$ ), and (4) large branches and stems (diameter $>6.4 \mathrm{~cm}$ ) following the procedure used by Kettering et al., (2001). All of these components were weighed directly in the field to obtain their fresh weight using a portable hanging balance with 100-kg capacity.

The subsamples for each component were collected from each sampled tree for ovendry weight analysis. Depending on the $\mathrm{DBH}$, three subsamples (with a minimum weight of $100 \mathrm{~g}$ for each subsample) were collected for each component. For large branches and stems, small branches and twigs, the subsamples were collected from the lower, middle and upper part of the tree for each component pool, whereas for leaves, the subsamples were taken from the total amount of the leaves taken from the tree. These subsamples were weighed in the field to obtain their fresh weight using a small balance with 2-kg capacity and stored in sealed plastic bags such that moisture was retained before sending them to the laboratory. A total of 592 subsamples from 51 sampled trees were sent to the Soil Science Laboratory of the Faculty of Agriculture in Sebelas Maret University (UNS), located in Surakarta, Central Java of Indonesia, for oven dry weight analysis. The wood and leave subsamples were oven-dried at $105^{\circ} \mathrm{C}$ until a relatively constant weight was obtained (Nelson et al., 1999; Ketterings et al., 2001). The total dry weight or Dry Matter (DM) of the stems were calculated using equation (1) (Jayaraman, 1999).

$T D W_{\text {stem }}=\frac{T D W_{\text {samples }}}{T F W_{\text {samples }}} \times T F W_{\text {ste }}$ 
where $\mathrm{TDW}_{\text {stem }}$ is the total dry weight of the stems, TDW ${ }_{\text {samples }}^{\text {stem }}$ is the total dry weight of the stems' subsamples, TFW ${ }_{\text {samples }}$ is the total fresh weight of the stems' subsamples and TFW stem $_{\text {is }}$ the total fresh weight of the stems. In addition, the stump height (l) and diameter $\left(\mathrm{D}_{\text {stump }}\right)$ were measured to estimate its volume using a cylinder volume formula as in equation (2), while its dry weight were estimated by multiplying its volume with the wood density of the stem (@) (Ketterings et al., 2001).

$$
V_{\text {stump }}=\frac{\pi\left(D_{\text {stump }}\right)^{2} l}{4}
$$

where $\mathrm{V}_{\text {stump }}$ is the stump volume, $\pi$ is a constant value (3.142), $\mathrm{D}_{\text {stump }}$ is the stump diameter and $\mathrm{l}$ is the stump height/length. Similarly, the total dry weight for all other components of the tree was calculated based on equation (1) by taking into account the total dry weight of the subsamples of the components, the total fresh weight of components' subsamples and the total fresh weight of the components. Moreover, the total dry weight of the sampled tree was calculated as the sum of the dry weight of its components and stump. This refers to the above-ground biomass of the tree $\left(\mathrm{AGB}_{\text {tree }}\right)$. Furthermore, data on $\mathrm{DBH}$ and $\mathrm{H}$ from destructive sampling and $\varrho$ data from the database of the World
Agroforestry Centre (CGIAR, 2008), which are available online, were used to develop sitespecific allometric equations.

\section{Data Analysis}

1. Regression models

Three types of regression models were used to develop the biomass equations: (1) Type I was developed using DBH ( $\mathrm{AGB}_{\text {tree }}-\mathrm{D}$ model), (2) Type II was developed using $\mathrm{DBH}$ and $\mathrm{H}$ ( $\mathrm{AGB}_{\text {tree }}-\mathrm{D}-\mathrm{H}$ model), and (3) Type III was developed using $\mathrm{DBH}, \mathrm{H}$ and $\varrho\left(\mathrm{AGB}_{\text {tree }}-\mathrm{D}-\right.$ $\mathrm{H}-\varrho$ ). Details of these models are presented in Table 1 . The data analysis for constructing the models was carried out using the SPSS ${ }^{\circledR} 14.0$ statistical package (SPSS Inc., 2005).

\section{Model selection}

The model selection was based on six statistical parameters, of which five are explained by Parresol (1999): (1) fit index (FI), (2) standard error of estimate in actual unit (Se), (3) coefficient of variation (CV) in percent, (4) Furnival's index $(I)$, and (5) corrected mean percent standard error of prediction $((\bar{S}(\%))$ or average (unsigned) deviation (Nelson et al., 1999; Basuki et al., 2009). The sixth parameter is the Akaike's Information Criterion/AIC (Akaike, 1974) calculated using equation (3). The best model will have the lowest $A I C$ value. where $A I C$ is the Akaike's Information

Table 1. Type of allometric equation models for AGB estimation

\begin{tabular}{ccc}
\hline Type & \multicolumn{1}{c}{ Allometric equation } & Model \\
\hline I. & $A G B_{\text {tree }}=\exp (a+b \times \operatorname{In}(D))$ & 1 \\
II. & $A G B_{\text {tree }}=\exp \left(a+b \times \operatorname{In}\left(D^{2} H\right)\right)$ & 2 \\
& $A G B_{\text {tree }}=\exp (a+b \times \operatorname{In}(D)+C \times \operatorname{In}(H))$ & 4 \\
III. & $A G B_{\text {tree }}=\exp \left(a+b \times \operatorname{In}\left(D^{2} H \tilde{n}\right)\right.$ & 3 \\
& $A G B_{\text {tree }}=\exp (a+b \times \operatorname{In}(D)+c \times \operatorname{In}(H)+d \times \operatorname{In}(\tilde{n}))$ & 5 \\
\hline
\end{tabular}

Notes: $\mathrm{AGB}_{\text {tree }}$ is the above-ground biomass per tree $\left(\mathrm{kg} \mathrm{DM}\right.$ tree $\left.{ }^{-1}\right)$, exp is $e$ raise to the power of, ln is natural logarithm, $D$ is the diameter at breast height $(\mathrm{cm}), H$ is the total tree height $(\mathrm{m}), \varrho$ is the wood density or the wood specific gravity $\left(\mathrm{g} \mathrm{cm}^{-3}\right)$, and $a, b, c$, and $d$ are the regression coefficients 


$$
A I C=C \mathrm{~h}\left(\frac{S_{e}}{C}\right)+2 p^{*}
$$

Criterion, $\mathrm{C}$ is the number of observed data, $\ln$ is natural logarithm, $\mathrm{SS}_{\mathrm{e}}$ is the residual sum of squares, and $\mathrm{p}^{*}$ is the number of parameters or coefficient in the models, including intercept.

3. Model prediction

During the analysis, the field data were transformed based on natural logarithm. This process introduced a systematic bias of the biomass estimates when they were backtransformed to the actual unit, whereby the biomass estimates were usually an underestimate of the actual biomass (Chave et al., 2005). For this reason, biomass estimates should be multiplied by a correction factor $(C F)$, which is a number close to 1 . In this study, the biomass estimates were corrected using equation (4) from Snowdon (1991).

$$
C_{S D}=\left(\frac{\frac{\sum_{i=1}^{n} Y_{i}}{n}}{\frac{\sum_{i=1}^{n} \hat{Y}_{i}}{n}}\right)
$$

where $\mathrm{CF}_{\mathrm{SD}}$ is the correction factor described by Snowdon (1991), $Y_{\mathrm{i}}$ is the observed data of the $i^{t h}$ sample, $\hat{Y}_{i}$ is the estimated data of the $i^{\text {th }}$ sample, and $n$ is the number of sample.

\section{RESULT AND DISCUSSION}

\section{A. Result}

All the regression models were statistically highly significant $(p<0.0001)$ and generally fitted the data well. The residuals for AGB models were relatively normally distributed and did not show any pattern (Appendix 2). The regression coefficient and the statistical summary for each model are presented in Table 2. Based on the model summary, Model 3 and 5 , which used $\mathrm{DBH}, \mathrm{H}$ and $\varrho$, performed better in estimating AGB. This was indicated by the higher $\mathrm{R}^{2}$ and adjusted $\mathrm{R}^{2}$ and the lower SEE and MSE. Between Model 3 and 5, Model 5 (which uses three single-variables), performed better than the combined variable of Model 3 . There was no difference in statistical summaries between Model 2 and 4 in relation to the type of variable used. Model 1, which is the simplest model, gave the lowest performance. However, in general, all the models had acceptable goodness-of-fit to the data indicated by $\mathrm{R}^{2}$ which was greater than 0.95 .

When using only $\mathrm{DBH}$ as a predictive variable (Model 1), $97 \%$ of the variation of the AGB (Table 2) was explained. Adding $H$ as a second predictor improved the performance of the model by increasing $\mathrm{R}^{2}$ and adjusted $\mathrm{R}^{2}$ and subsequently reducing SEE and MSE. Since the $\mathrm{R}^{2}$ for Model 1 was already high, adding $\mathrm{H}$ has only slightly increased the $\mathrm{R}^{2}$. For combined variable (Model 2), $\mathrm{R}^{2}$ has increased relatively by $1.1 \%$, while $S E E$ was reduced relatively by $19.8 \%$. Adding $\varrho$ to the model as the third predictor has slightly improved the performance of the models. As a combined variable (Model 3 to Model 2), @ improved the $\mathrm{R}^{2}$ by $0.4 \%$ and reduced the $S E E$ by $11.2 \%$. As an independent variable (Model 5 to Model 4), $\varrho$ increased the $\mathrm{R}^{2}$ by $0.6 \%$ and decreased the SEE by $15.0 \%$.

The model selection was based on the comparison parameters explained by Parresol (1999) and is summarised in Table 3. Based on these parameters, Model 5, which used three independent variables, outperformed all other models, which is indicated by the highest FI value and the lowest $\mathrm{S}, \mathrm{CV}, \mathrm{I}, \overline{\mathrm{S}}(\%)$, and $\mathrm{AIC}$ values. Adding $H$ to the $\mathrm{DBH}$ reduced the Se up to $\sim 50 \mathrm{~kg}$, the $C V$ (as a measure of dispersion around the mean) up to $\sim 6 \%$ and the $\bar{S}(\%)$ (as a measure of precision) up to $\sim 4 \%$ (noncorrected models). Based on the comparison parameters in Table 3, Model 2 performed slightly better in estimating AGB in the study area, which previously could not be observed from the statistical summary of the models in Table 2. Adding the $\mathrm{H}$ and $\varrho$ together to the $\mathrm{DBH}$ in the AGB models reduced the Se up to 
Table 2. Regression coefficients and statistical summary for each AGB model

\begin{tabular}{|c|c|c|c|c|c|c|c|}
\hline \multirow{2}{*}{ Model } & \multicolumn{3}{|c|}{ Coefficient } & \multicolumn{4}{|c|}{ Model Summary } \\
\hline & Symbol & Value & SE & $R^{2}$ & Adjusted $R^{2}$ & SEE & MSE \\
\hline \multirow{2}{*}{1.} & $a$ & -2.551 & 0.208 & \multirow{2}{*}{0.970} & \multirow{2}{*}{0.969} & \multirow{2}{*}{0.333} & \multirow{2}{*}{0.111} \\
\hline & $b$ & 2.660 & 0.067 & & & & \\
\hline \multirow[t]{2}{*}{2.} & $a$ & -3.398 & 0.182 & \multirow[t]{2}{*}{0.981} & \multirow[t]{2}{*}{0.980} & \multirow[t]{2}{*}{0.267} & \multirow[t]{2}{*}{0.071} \\
\hline & $b$ & 0.995 & 0.020 & & & & \\
\hline \multirow[t]{2}{*}{3.} & $a$ & -2.965 & 0.154 & \multirow[t]{2}{*}{0.985} & \multirow[t]{2}{*}{0.984} & \multirow[t]{2}{*}{0.237} & \multirow[t]{2}{*}{0.056} \\
\hline & $b$ & 0.990 & 0.018 & & & & \\
\hline \multirow[t]{3}{*}{4.} & $a$ & -3.580 & 0.256 & \multirow[t]{3}{*}{0.981} & \multirow[t]{3}{*}{0.980} & \multirow[t]{3}{*}{0.267} & \multirow[t]{3}{*}{0.071} \\
\hline & $b$ & 1.827 & 0.166 & & & & \\
\hline & $c$ & 1.229 & 0.232 & & & & \\
\hline \multirow[t]{4}{*}{5.} & $a$ & -3.126 & 0.240 & \multirow[t]{4}{*}{0.987} & \multirow[t]{4}{*}{0.986} & \multirow[t]{4}{*}{0.227} & \multirow[t]{4}{*}{0.051} \\
\hline & $b$ & 2.011 & 0.147 & & & & \\
\hline & $c$ & 0.966 & 0.206 & & & & \\
\hline & $d$ & 0.641 & 0.145 & & & & \\
\hline
\end{tabular}

Notes: $\mathrm{SE}=$ standard error of the coefficient, $\mathrm{R}^{2}=$ coefficient of determination, $S E E=$ standard error of the estimate and MSE $=$ mean square error. All models and coefficients are statistically significant at $\alpha=0.05$ ( $p$ $<0.0001$, except for coefficient $d$ in Model 5: $p=0.001$ )

Table 3. A summary of comparison parameters of the developed models for AGB estimation

\begin{tabular}{|c|c|c|c|c|c|c|c|c|}
\hline \multirow{2}{*}{ Model } & \multicolumn{7}{|c|}{ Comparison parameters } & \multirow{2}{*}{$C F$} \\
\hline & FI & Se & $\mathrm{CV}$ & $I$ & $\bar{S}(\%)$ & AIC & Bias & \\
\hline \multirow[t]{2}{*}{1} & 0.91 & 337.90 & 40.59 & 84.79 & 25.97 & 595.88 & -19.74 & $\mathrm{NC}$ \\
\hline & 0.91 & 339.84 & 40.82 & 84.79 & 26.63 & 596.47 & 0.00 & $1.024^{a}$ \\
\hline \multirow[t]{2}{*}{2} & 0.93 & 288.09 & 34.60 & 67.99 & 22.21 & 579.61 & -22.32 & $\mathrm{NC}$ \\
\hline & 0.93 & 287.41 & 34.52 & 67.99 & 22.51 & 579.37 & 0.00 & $1.028^{\mathrm{a}}$ \\
\hline \multirow[t]{2}{*}{3} & 0.93 & 283.79 & 34.09 & 60.35 & 20.71 & 578.08 & -15.47 & $\mathrm{NC}$ \\
\hline & 0.93 & 285.99 & 34.35 & 60.35 & 21.07 & 578.87 & 0.00 & $1.019^{\mathrm{a}}$ \\
\hline \multirow[t]{2}{*}{4} & 0.93 & 288.32 & 34.63 & 67.99 & 22.10 & 580.64 & -23.68 & $\mathrm{NC}$ \\
\hline & 0.93 & 286.92 & 34.46 & 67.99 & 22.41 & 580.15 & 0.00 & $1.029^{\mathrm{a}}$ \\
\hline \multirow[t]{2}{*}{5} & 0.96 & 233.52 & 28.05 & 57.80 & 19.32 & 560.07 & -17.42 & $\mathrm{NC}$ \\
\hline & 0.96 & 232.94 & 27.98 & 57.80 & 19.52 & 559.82 & 0.00 & $1.021^{\mathrm{a}}$ \\
\hline
\end{tabular}

Notes: $F I=$ Fit Index, $\mathrm{S}_{\mathrm{e}}=$ Standard error in actual unit, $C V=$ Coefficient of Variation, $I=$ Furnival's index, $\bar{S}(\%)=$ Average deviation, $A I C=$ Akaike's Information Criterion, $N C=$ Not Corrected, a $=$ corrected using formula from Snowdon (1991)

$\sim 104 \mathrm{~kg}$, the $C V$ up to $\sim 12 \%$ and the $\bar{S}(\%)$ up to $\sim 7 \%$ (non-corrected models). In this case, Model 5 (which uses three single predictors) performed better than Model 3 (which uses a compound of three variables). Adding extra variables into the models increased the FI values up to $5 \%$.

Log-transformation of the datasets during the model construction resulted in the underestimation of the actual biomass as indicated by the negative values of the bias (Table 3). The underestimation of actual biomass was also observed using a scatter plot of predicted AGB against observed AGB as presented in Appendix 3. Multiplying the predicted biomass by a $C F$ was intended to remove the systematic bias due to back-transformation. In this study, the formula of Snowdon (1991) was used. 
Table 4. Mean average deviation $(\bar{S}(\%))$ per DBH class for each model

\begin{tabular}{crrrr}
\hline \multirow{2}{*}{ Model } & \multicolumn{4}{c}{ Mean $\bar{S}(\%)$} \\
\cline { 2 - 5 } & $\mathrm{DBH}<=10 \mathrm{~cm}$ & $10 \mathrm{~cm}<\mathrm{DBH}<=30 \mathrm{~cm}$ & $30 \mathrm{~cm}<\mathrm{DBH}<=50 \mathrm{~cm}$ & $\mathrm{DBH}>50 \mathrm{~cm}$ \\
\hline 1 & 29.10 & 28.26 & 21.15 & 30.49 \\
2 & 25.75 & 22.77 & 19.18 & 23.53 \\
3 & 22.87 & 22.92 & 18.31 & 18.80 \\
4 & 26.44 & 22.34 & 18.82 & 23.53 \\
5 & 21.79 & 20.79 & 16.60 & 18.49 \\
\hline
\end{tabular}

Furthermore, regardless of use, the CF did not necessarily improve the performance of the models in total (Table 3), as evaluated from the increased values of $\mathrm{S}_{\mathrm{e}}, C V, \overline{\mathrm{S}}(\%)$, and AIC. However, the CF formula from Snowdon (1991) was useful in removing the bias of the models.

This study was conducted in peat swamp forests that have been actively logged by a commercial company. Following the current silvicultural system, the company is extracting the commercial tree species with a minimum DBH of $30 \mathrm{~cm}$ (Istomo et al., 2010). Therefore, it is important to evaluate the $\bar{S}(\%)$ based on the $\mathrm{DBH}$ classes. This information is useful in selecting the model for the biomass study in relation to the forest condition, especially the distribution of the diameters. The developed models have generally low $\bar{S}(\%)$ of AGB (< $30 \%$; Table 4). The exception was Model 1 with a DBH greater than $50 \mathrm{~cm}(30.5 \%)$. All of the equations tended to have a higher $\bar{S}(\%)$ when the smaller DBH classes were considered. For DBH class less than $10 \mathrm{~cm}$, the $\bar{S}(\%)$ ranged from $21.8 \%$ to $29.1 \%$, while for $\mathrm{DBH}$ class $10-30 \mathrm{~cm}$, the $\bar{S}(\%)$ ranged from $20.8 \%$ to $28.3 \%$. This $\bar{S}(\%)$ decreased with larger $\mathrm{DBH}$ classes giving common values of less than $20 \%$, except for Model 1 (30.5\% at DBH $>50 \mathrm{~cm})$. In general, Model 5 provided the most precise estimate of AGB in the study area, as indicated by the smallest values of $\bar{S}(\%)$ in all $\mathrm{DBH}$ classes. The visualization of the $\bar{S}(\%)$ based on the DBH classes is presented in Figure 2.

\section{B. Discussion}

\section{Allometric equations}

The selection or development of reliable allometric biomass equations is an essential step in estimating the AGB of the forest (Crow,

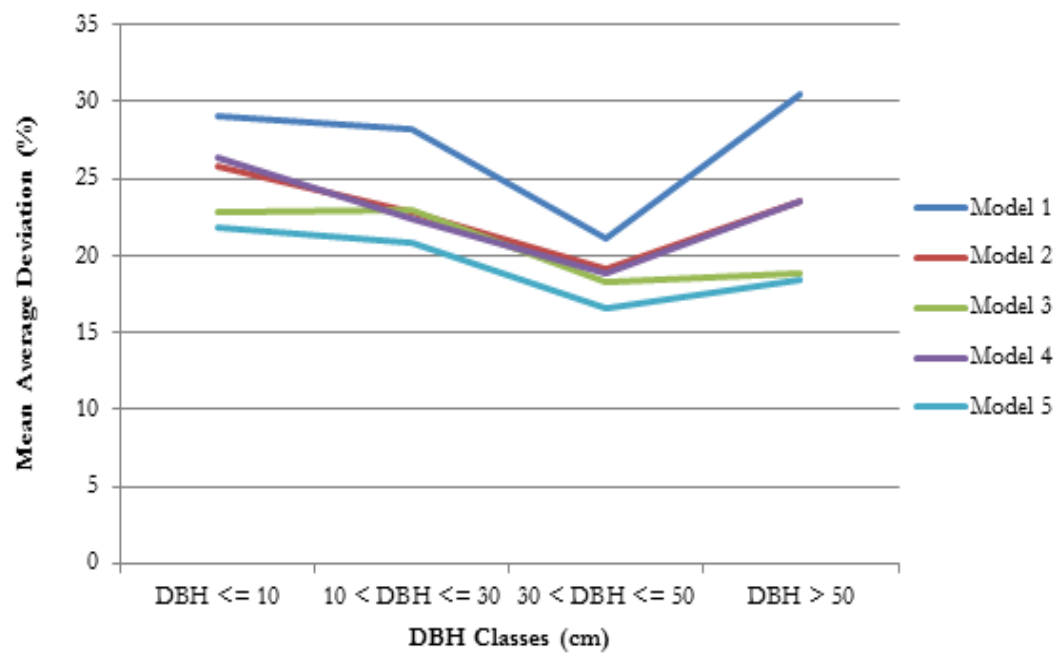

Figure 2. The mean average deviation $(\bar{S}(\%))$ based on DBH classes for each allometric model 
1978; Cunia, 1987; Brown et al., 1989; Chave et al., 2001; Houghton et al., 2001; Chave et al., 2004; Chave et al., 2005). The basic idea of developing allometric equation is to estimate the difficult-to-measure tree characteristics (e.g. biomass) from one that is relatively easy to measure such as DBH (Goetz et al., 2010). Chave et al. (2004) pointed out that the most important source of error in forest biomass studies is the incorrect or inappropriate choice of allometric equation. Species-specific allometric equations, which are commonly used in the biomass study of temperate forest (e.g. Ter-Mikaelian and Korzukhin, 1997; Jenkins et al., 2003; Zianis et al., 2005), are not applicable to tropical forest which has high number of species per ha. In this case, the mixed-species allometric equations are more suitable (Ketterings et al., 2001; Chave et al., 2005).

Many studies have been conducted to develop mixed-species allometric equation for biomass estimation in tropical forest (e.g. Brown et al., 1989; Brown et al., 1995; Brown, 1997; Araujo et al., 1999; Nelson et al., 1999; Chambers et al., 2001; Chave et al., 2001; Ketterings et al., 2001; Chave et al., 2005; Nogueira et al., 2008b; Basuki et al., 2009; Kenzo et al., 2009a; Kenzo et al., 2009b). However, few studies on allometric biomass equations have been conducted for peat swamp forests and the results are usually not publicly accessible (Verwer and Meer, 2010; Solichin et al., 2011). Therefore, it is expected that this study will contribute significantly to the improvement of biomass and carbon estimation accuracies in peat swamp forests.

$\mathrm{DBH}$ as a variable has been found to have a strong correlation with biomass (with $\mathrm{R}^{2}$ typically more than 95\%). Previous studies recommended the application of the allometric equation which uses only $\mathrm{DBH}$, although largely for practical reason (e.g. Brown, 1997; Basuki et al., 2009; Návar, 2009). This is because the $\mathrm{DBH}$ is more easily measured in the forest and collected during the regular forest inventory (Segura and Kanninen, 2005). In this study, allometric equation with only $\mathrm{DBH}$ as a predictor (Model 1) had an $\mathrm{R}^{2}$ of $97.0 \%$. The
$\bar{S}(\%)$ value was $26.6 \%$ which is comparable with the $\bar{S}(\%)$ of the DBH-only model in mixed-dipterocarp forest in East Kalimantan (Basuki et al., 2009). This statistic indicates the average size of error as a percent of the mean and can be used as a precision indicator (Parresol, 1999), where the lower the value the higher the precision. Although the DBH-only model is more practical, the model tends largely to underestimate or overestimate the actual biomass. For example, Parastemon urophyllum and Palaquium obovatum with the same $\mathrm{DBH}$ of $7.6 \mathrm{~cm}$ have weights of $35.15 \mathrm{~kg}$ and $8.94 \mathrm{~kg}$, respectively. Using only $\mathrm{DBH}$ as a predictive variable, Model 1 estimated AGB for these two tree species to be $17.6 \mathrm{~kg}$. As a result, the $\bar{S}$ $(\%)$ for P. obovatum was very large $(96.8 \%)$, and almost twice than the $\bar{S}(\%)$ for $P$. urophyllum $(49.9 \%)$. This is because the architecture of the tree is not accounted in the model (i.e. the $\mathrm{H}$ differs being $11.52 \mathrm{~m}$ and $7.83 \mathrm{~m}$, respectively). For trees with larger $\mathrm{DBH}$, the $\bar{S}(\%)$ is relatively lower but the actual residual is large. Therefore, adding $\mathrm{H}$ as a second predictor in the model is important.

Numerous other studies on forest biomass (e.g. Crow, 1978; Nelson et al., 1999; Ketterings et al., 2001; Chave et al., 2005; Cole and Ewel, 2006; Fehrmann and Kleinn, 2006; Wang, 2006) have previously noted that adding $\mathrm{H}$ can improve the model performance. Adding $\mathrm{H}$ to $\mathrm{DBH}$ in the AGB models increases the $\mathrm{R}^{2}$ by up to $1.7 \%$ relative to Model 1 . Although adding $\mathrm{H}$ can only marginally increase the $\mathrm{R}^{2}$, the $S E E$ was reduced significantly (up to $22 \%$ ). In addition, the Se was reduced as well as the $C V$ and the $\bar{S}(\%)$. Using Model 2, the estimated biomass values for P. urophyllum and P. obovatum were $22.13 \mathrm{~kg}$ and $15.07 \mathrm{~kg}$, respectively. The $\bar{S}$ (\%) was reduced to $68.5 \%(-28.3 \%)$ and $37.0 \%$ $(-12.9 \%)$, respectively.

Model 4, which considers $H$ as an independent variable, provided a better estimate. The estimated biomass values for $P$. urophyllum and $P$. obovatum were $14.64 \mathrm{~kg}$ and $23.52 \mathrm{~kg}$, respectively and the $\bar{S}(\%)$ values were $63.7 \%$ and $33.1 \%$, respectively. The advantage 
of adding $\mathrm{H}$ was more evident for larger trees. For example, Ilex macrophylla and Gonystylus bancanus have the same DBH $(40.0 \mathrm{~cm})$ but their $H$ and $\mathrm{AGB}_{\text {tree }}$ were different, with these being $24.14 \mathrm{~m}$ and $30.21 \mathrm{~m}$, and $1186.95 \mathrm{~kg}$ and $1779.28 \mathrm{~kg}$, respectively. The estimated $\mathrm{AGB}_{\text {tree }}$ using Model 1 gave $1458.87 \mathrm{~kg}$ for both tree species and the $\bar{S}(\%)$ values were $22.9 \%$ and $18.0 \%$, respectively. When Model 4 was used to estimate the biomass of these trees, the $\bar{S}(\%)$ values for I. macrophylla and G. bancanus became $2.2 \%$ and $10.1 \%$, respectively.

Further improvement can be achieved by adding $\varrho$ to the model. The $\varrho$ is an important tree parameter in estimating biomass, in particular for larger trees (Baker et al., 2004; Chave et al., 2005; Nogueira et al., 2008a). This study found that allometric equation which uses three independent variables (i.e. $\mathrm{DBH}, H$ and $\varrho$ ) gave the best performance (Model 5) and supports previous studies (e.g. Nelson et al., 1999; Chave et al., 2005). Incorporating $\varrho$ into the $\mathrm{DBH}-\mathrm{H}$ models increased the $\mathrm{R}^{2}$ by less than $1 \%$ but reduced the relative $S E E$ by up to $\sim 15 \%$. Adding $\mathrm{H}$ and $\varrho$ together to $\mathrm{DBH}$ increased the performances of the model significantly based on the comparison parameters. However, for some tree species, the $\varrho$ was not an important parameter. For example, Shorea uliginosa and $P$. urophyllum have the same DBH of $43.70 \mathrm{~cm}$ and relatively the same $H(33.30 \mathrm{~m}$ and $33.46 \mathrm{~m})$ and also dry weight biomass $(2300.50 \mathrm{~kg}$ and $2392.44 \mathrm{~kg}$ ), but their $\varrho$ values were different $\left(0.640 \mathrm{~g} \mathrm{~cm}^{-3}\right.$ and $\left.1.040 \mathrm{~g} \mathrm{~cm}^{-3}\right)$. In this case, the most important factor was the difference in canopy structure (branching system). $S$. uliginosa tends to have a heavier canopy with more branches and bigger leaves compared to P. urophyllum. Thus, although P. urophyllum has significantly higher $\varrho$, the dry weight biomass values were not largely different. For these species, Model 5, which uses three independent variables, resulted in lower precision than Model 4, which uses two independent variables (without $\varrho$ ). The $\bar{S}(\%)$ values were $13.9 \%$ and 13.6\% (Model 5) and 7.9\% and 10.9\% (Model 4). Basuki et al. (2009) found that $\varrho$ is not statistically significant for Dipterocarpus, Hopea and Shorea in East Kalimantan. Nelson et al. (1999) also found that $\varrho$ is not significant for Bellucia species in the central Amazon.

The results of the model comparison indicated that increasing number of parameters or independent variables increases the performance of the model. However, it is important to note that including more variables in the model increases the regression error or uncertainty of the biomass through error propagation (Chave et al., 2004; Chave et al., 2005). In addition, information on speciesspecific $\varrho$ for peat swamp forest species is not always available in the database of the World Agroforestry Centre (CGIAR, 2008), although the average value of the wood density for the genus can be used instead (Krisnawati etal., 2012), and $\mathrm{H}$ is usually not collected during the forest inventory (Chave et al., 2005). An alternative way to acquire $H$ information is by constructing a stand-specific allometric relationship between $H$ with $\mathrm{DBH}$ from destructively sampled trees and then using the developed equation to predict the $H$ for the rest of the trees being studied (Brown et al., 1989; Chave et al., 2005), although errors in this relationship need to be accounted for. Adding $H$ can improve the model's performance, but $H$ is rarely used in practice because of two reasons: (1) measuring $H$ in a forest ecosystem, particularly in dense tropical forests is much more difficult and time consuming but less accurately estimated than DBH (Gower et al., 1999); and (2) adding $H$ into the model increases the regression error in the biomass estimate (Chave et al., 2005).

2. The applicability of the developed sitespecific allometric equations

The developed models are considered as the site-specific allometric equations for the study area as the sampled trees that were used to construct the model were harvested in situ. The models should be used in the biomass studies of peat swamp forests within their $\mathrm{DBH}$ range $(5.2-62.7 \mathrm{~cm})$. It is important to consider the $\mathrm{DBH}$ range in applying allometric equations as the error tends to increase with increases in 
DBH. Applying allometric equations outside the $\mathrm{DBH}$ range will result in bigger errors, especially for the larger trees.

3. The limitations of the developed sitespecific allometric equations

There are several limitations in developing site-specific allometric models for AGB in this study. Firstly, during the oven-dry weight analysis, the sub-subsampled tree components were used instead of the subsampled ones. Preanalysis was carried out to find the moisture differences between field fresh weight and laboratory fresh weight using 44 randomly selected subsampled tree components (stems, branches, twigs, and leaves). The average percent differences were $2.8 \%, 4.0 \%, 4.9 \%$, and $5.9 \%$ for stems, branches, twigs and leaves, respectively. The correction for each component was conducted by adding the lower value of confidence interval in paired samples t-test as suggested by Statistical Consulting Unit at the Australian National University, with these being $7.60 \mathrm{~g}, 6.86 \mathrm{~g}, 7.02 \mathrm{~g}$, and $6.58 \mathrm{~g}$ for stems, branches, twigs, and leaves, respectively. This correction may introduce a systematic bias in the predicted biomass.

Secondly, this study used a limited number of species for constructing the allometric models (11 species in total with nine dominant species) within a relatively narrow $\mathrm{DBH}$ range (i.e. 5.2-62.7 cm). Based on the plot measurement during the field campaign, approximately 53 tree species have been identified (mostly by their local name) and four species were unknown. Considering the number of sampled tree species across the DBH range, the models may not well represent the peat swamp forest at large (Chave et al., 2005). Third, the tree species were recorded by their local names and because there are different local names for the same species and different species with the same local name, identifying the correct scientific name in the literature or database can lead to misidentification. Furthermore, this can lead to an incorrect use of $\varrho$ estimates from the database.

\section{CONCLUSION}

In this study five site-specific allometric equations have been developed based on destructively sampled trees. Model 5 , which used $\mathrm{DBH}, H$ and $\varrho$ as predictive variables, has the best performance in estimating the AGB of the study area. As long as reliable data are available for those variables, the application of Model 5 is recommended in estimating the AGB of peat swamp forests. However, when reliable data on $H$ and $\varrho$ are unavailable, the simplest model that uses only $\mathrm{DBH}$ as a predictor (Model 1) can be applied. The accuracy and applicability of the site-specific allometric equations could be improved further by adding more sampled trees from different tree species and/or with a wider DBH range. Considering the importance of wood density in AGB estimation and the lack of this information for peat swamp forest tree species, research should be dedicated to analysing the wood density of the dominant tree species comprising the majority of the AGB density in the study area. In addition, it is important to test the models at other sites (peat swamp forest at different locations). Combining the dataset from a wide-range of geographical area may improve the generic applicability of the models.

\section{ACKNOWLEDGEMENT}

The author is very grateful to Prof. Richard Lucas, Assoc. Prof. Cris Brack and Dr. Bruce Doran for their invaluable comments and supports. The author is also indebted to Assoc. Prof. Luca Tacconi for providing financial support to conduct this research.

\section{REFERENCES}

Aboal, J. R., Arevalo, J. R., \& Fernandez, A. (2005). Allometric relationships of different tree species and stand above ground biomass in the Gomera laurel forest (Canary Islands). Flora, 200, 264-274.

Akaike, H. (1974). A new look at the statistical model identification. IEEE Transactions on Automatic Control, 19(6), 716-723. 
Anaya, J. A., Chuvieco, E., \& Palacios-Orueta, A. (2009). Aboveground biomass assessment in Colombia: A remote sensing approach. Forest Ecology and Management, 257(4), 1237-1246.

Araujo, T. M., Higuchi, N., \& Junior, J. A. d. C. (1999). Comparison of formulae for biomass content determination in a tropical rain forest site in the state of Para, Brazil. Forest Ecology and Management, 117(1-3), 43-52.

Baker, T. R., Phillips, O. L., Malhi, Y., Almeida, S., Arroyo, L., Fiore, A. D., \& Martínez, R. V. (2004). Variation in wood density determines spatial patterns in Amazonian forest biomass. Global Change Biology, 10(5), 545-562.

Banskota, A., Wynne, R., Johnson, P., \& Emessiene, B. (2011). Synergistic use of very highfrequency radar and discrete-return lidar for estimating biomass in temperate hardwood and mixed forests. Annals of Forest Science, 1-10. doi:10.1007/s13595-011-0023-0

Basuki, T. M., van Laake, P. E., Skidmore, A. K., \& Hussin, Y. A. (2009). Allometric equations for estimating the above-ground biomass in tropical lowland Dipterocarp forests. Forest Ecology and Management, 257(8), 1684-1694.

Brown, I. F., Martinelli, L. A., Thomas, W. W., Moreira, M. Z., Cid Ferreira, C. A., \& Victoria, R. A. (1995). Uncertainty in the biomass of Amazonian forests: An example from Rondônia, Brazil. Forest Ecology and Management, 75(1-3), 175-189.

Brown, S. (1997). Estimating biomass and biomass change of tropical forests: a primer. Rome, Italy: Food and Agriculture Organization of the United Nations (FAO).

Brown, S. (2002). Measuring carbon in forests: current status and future challenges. Environmental Pollution, 116(3), 363-372.

Brown, S., Gillespie, A. J. R., \& Lugo, A. E. (1989). Biomass estimation methods for tropical forests with applications to forest inventory data. Forest Science, 35, 881-902.

CGIAR. (2008). Wood density database. Retrieved 15 January 2011, from http:// www.worldagroforestry.org/sea/Products/ AFDbases/WD/Index.htm

Chambers, J. Q., Santos, J. d., Ribeiro, R. J., \& Higuchi, N. (2001). Tree damage, allometric relationships, and above-ground net primary production in central Amazon forest. Forest Ecology and Management, 152(1-3), 73-84.

Chave, J., Andalo, C., Brown, S., Cairns, M., Chambers, J., Eamus, D., \& Yamakura, T. (2005). Tree allometry and improved estimation of carbon stocks and balance in tropical forests. Oecologia, 145(1), 87-99.

Chave, J., Condit, R., Aguilar, S., Hernandez, A., Lao, S., \& Perez, R. (2004). Error propagation and scaling for tropical forest biomass estimates. Philosophical Transactions of the Royal Society of London, 03TB055D (on-line), 1-12.

Chave, J., Condit, R., Lao, S., Caspersen, J. P., Foster, R. B., \& Hubbell, S. P. (2003). Spatial and temporal variation of biomass in a tropical forest: results from a large census plot in Panama. Journal of Ecology, $91(2), 240-252$. doi: 10.1046/j.1365-2745.2003.00757.x

Chave, J., Riera, B., \& Dubois, M.-A. (2001). Estimation of biomass in a neotropical forest of French Guiana: spatial and temporal variability. Journal of Tropical Ecology, 17(1), 7996.

Clark, D. A., Brown, S., Kicklighter, D. W., Chambers, J. Q., Thomlinson, J. R., \& Ni, J. (2001). Measuring net primary production in forests: concepts and field methods. Ecological Applications, 11(2), 356-370.

Cole, T. G., \& Ewel, J. J. (2006). Allometric equations for four valuable tropical tree species. Forest Ecology and Management, 229(1-3), 351-360.

Crow, T. R. (1978). Common regressions to estimate tree biomass in tropical stands. Forest Science, 24, 110-114.

Cunia, T. (1987). Error of forest inventory estimates: its main components. In E. H. Wharton \& T. Cunia (Eds.), Estimating tree biomass regressions and their error, Northeastern Forest Experimental Station, Brooomall, Pennsylvania: USDA.

FAO. (2004). National Forest Inventory: Field manual template. Rome: FAO.

FAO. (2006). Global Forest Resources Assessment 2005: progress towards sustainable forest management FAO Forestry Paper: 147 (pp. pp. 350). Rome, Italy: Food and Agriculture Organization of the United Nations (FAO).

Fehrmann, L., \& Kleinn, C. (2006). General considerations about the use of allometric equations for biomass estimation on the 
example of Norway spruce in central Europe. Forest Ecology and Management, 236(2-3), 412421.

Foody, G. M., Cutler, M. E., McMorrow, J., Pelz, D., Tangki, H., Boyd, D. S., \& Douglas, I. (2001). Mapping the biomass of Bornean tropical rain forest from remotely sensed data. Global Ecology and Biogeography, 10(4), 379-387.

Gibbs, H. K., Brown, S., Niles, J. O., \& Foley, J. A. (2007). Monitoring and estimating tropical forest carbon stocks: making REDD a reality. Environmental Research Letters, 2(045023), 1-13.

Goetz, S., Achard, F., Joosten, H., Kanamaru, H., Lehtonen, A., Menton, M., \& Wattenbach, M. (2010). Comparison of methods for measuring and assessing carbon stocks and carbon stock changes in terrestrial carbon pools Systematic Review No. 09-016 (previously SR77): Collaboration for Environmental Evidence.

Gower, S. T., Kucharik, C. J., \& Norman, J. M. (1999). Direct and indirect estimation of leaf area index, fAPAR, and net primary production of terrestrial ecosystems. Remote Sensing of Environment, 70, 29-51.

Hirano, T., Segah, H., Harada, T., Limin, S., June, T., Hirata, R., \& Osaki, M. (2007). Carbon dioxide balance of a tropical peat swamp forest in Kalimantan, Indonesia. Global Change Biology, 13(2), 412-425. doi:10.1111/j.13652486.2006.01301.x

Hooijer, A., Page, S., Canadell, J. G., Silvius, M., Kwadijk, J., Wösten, H., \& Jauhiainen, J. (2009). Current and future CO2 emissions from drained peatlands in Southeast Asia. Biogeosciences Discussions, 6(4), 7207-7230.

Hooijer, A., Page, S., Canadell, J. G., Silvius, M., Kwadijk, J., Wösten, H., \& Jauhiainen, J. (2010). Current and future CO2 emissions from drained peatlands in Southeast Asia. Biogeosciences, 7(5), 1505-1514.

Hooijer, A., Silvius, M., Wosten, H., \& Page, S. (2006). PEAT-CO2: assessment of CO2 emissions from drained peatlands in SE Asia (pp. 41p.). Delft, the Netherlands: Delft Hydraulics Report QA 3943.

Houghton, R. A. (2005). Aboveground forest biomass and the global carbon balance. Global Change Biology, 11(6), 945-958. doi: 10.1111/j.1365-2486.2005.00955.x
Houghton, R. A., Lawrence, K. T., Hackler, J. L., \& Brown, S. (2001). The spatial distribution of forest biomass in the Brazilian Amazon: a comparison of estimates. Global Change Biology, 7(7), 731-746. doi:10.1046/j.13652486.2001.00426.x

Istomo. (2002). Kandungan fosfor dan kalsium serta penyebarannya pada tanah dan tumbuhan butan rawa gambut: studi kasus di Wilayah Bagian Kesatuan Pemangkuan Hutan Bagan, Kabupaten Rokan Hilir, Riau (PhD), Institut Pertanian Bogor, Bogor.

Istomo, Komar, T. E., Tata, M. H. L., Sumbayak, E. S. S., \& Rahma, A. (2010). Evaluasi Sistem Silvikultur Hutan Rawa Gambut di Indonesia (in Indonesian). Bogor, Indonesia: ITTOCITES Project and Pusat Penelitian dan Pengembangan Hutan dan Konservasi Alam, Kementerian Kehutanan

Jaenicke, J., Rieley, J. O., Mott, C., Kimman, P., \& Siegert, F. (2008). Determination of the amount of carbon stored in Indonesian peatlands. Geoderma, 147(3-4), 151-158.

Jayaraman, K. (1999). A statistical manual for forestry research Forestry Research Support Programme for Asia and the Pacific (pp. 234). Bangkok, Thailand: Food and Agriculture Organization of the United Nations (FAO) Regional Office for Asia and the Pacific.

Jenkins, J. C., Chojnacky, D. C., Heath, L. S., \& Birdsey, R. A. (2003). National-scale biomass estimators for United States tree species. Forest Science, 49, 12-35.

Jepsen, M. R. (2006). Above-ground carbon stocks in tropical fallows, Sarawak, Malaysia. Forest Ecology and Management, 225(1-3), 287-295.

Kenzo, T., Furutani, R., Hattori, D., Kendawang, J., Tanaka, S., Sakurai, K., \& Ninomiya, I. (2009). Allometric equations for accurate estimation of above-ground biomass in logged-over tropical rainforests in Sarawak, Malaysia. Journal of Forest Research, 14(6), 365-372.

Kenzo, T., Ichie, T., Hattori, D., Itioka, T., Handa, C., Ohkubo, T., \& Ninomiya, I. (2009). Development of allometric relationships for accurate estimation of above- and belowground biomass in tropical secondary forests in Sarawak, Malaysia. Journal of Tropical Ecology, 25(04), 371-386. doi:10.1017/ S0266467409006129 
Ketterings, Q. M., Coe, R., van Noordwijk, M., Ambagau', Y., \& Palm, C. A. (2001). Reducing uncertainty in the use of allometric biomass equations for predicting above-ground tree biomass in mixed secondary forests. Forest Ecology and Management, 146(1-3), 199-209.

Krisnawati, H., Adinugroho, W. C., \& Imanuddin, R. (2012). Monograph Allometric Models for Estimating Tree Biomass at V arious Forest Ecosystem Types in Indonesia. Bogor, Indonesia: Research and Development Center for Conservation and Rehabilitation, Forestry Research and Development Agency, Ministry of Forestry.

Krisnawati, H., \& Imanuddin, R. (2011). Carbon stock estimation of aboveground pool based on forest inventory (permanent sample plot) data: a case study in peat swamp forest in Jambi Workshop on Tropical Wetland Ecosystems of Indonesia: Science Needs to Address Climate Change Adaptation and Mitigation, 11-14 April 2011 (pp. 6pp). Sanur Beach Hotel, Bali, Indonesia: US Forest Service, FORDA Ministry of Forestry of Indonesia, CIFOR and USAID.

Labrecque, S., Fournier, R. A., Luther, J. E., \& Piercey, D. (2006). A comparison of four methods to map biomass from Landsat-TM and inventory data in western Newfoundland. Forest Ecology and Management, 226(1-3), 129144.

Losi, C. J., Siccama, T. G., Condit, R., \& Morales, J. E. (2003). Analysis of alternative methods for estimating carbon stock in young tropical plantations. Forest Ecology and Management, 184(1-3), 355-368.

Lu, D. (2006). The potential and challenge of remote sensing-based biomass estimation. International Journal of Remote Sensing, 27(7), 1297-1328.

Lucas, R. M., Cronin, N., Lee, A., Moghaddam, M., Witte, C., \& Tickle, P. (2006). Empirical relationships between AIRSAR backscatter and LiDAR-derived forest biomass, Queensland, Australia. Remote Sensing of Environment, 100(3), 407-425.

Ludang, Y., \& Jaya, H. P. (2007). Biomass and carbon content in tropical forest of Central Kalimantan. Journal of Applied Sciences in Environmental Sanitation, 2(1), 7-12.

Maltby, E., \& Immirzi, P. (1993). Carbon dynamics in peatlands and other wetland soils regional and global perspectives. Chemosphere, 27(6),
999-1023.

Návar, J. (2009). Allometric equations for tree species and carbon stocks for forests of northwestern Mexico. Forest Ecology and Management, 257(2), 427-434.

Nelson, B. W., Mesquita, R., Pereira, J. L. G., Garcia Aquino de Souza, S., Teixeira Batista, G., \& Bovino Couto, L. (1999). Allometric regressions for improved estimate of secondary forest biomass in the central Amazon. Forest Ecology and Management, 117(1-3), 149-167.

Nogueira, E. M., Fearnside, P. M., \& Nelson, B. W. (2008). Normalization of wood density in biomass estimates of Amazon forests. Forest Ecology and Management, 256(5), 990-996.

Nogueira, E. M., Fearnside, P. M., Nelson, B. W., Barbosa, R. I., \& Keizer, E. W. H. (2008). Estimates of forest biomass in the Brazilian Amazon: New allometric equations and adjustments to biomass from wood-volume inventories. Forest Ecology and Management, 256(11), 1853-1867.

Page, S. E., Rieley, J. O., Shotyk, W., \& Weiss, D. (1999). Interdependence of peat and vegetation in a tropical peat swamp forest. Philosophical Transactions of the Royal Society of London. Series B: Biological Sciences, 354(1391), 1885-1897.

Page, S. E., Siegert, F., Rieley, J. O., Boehm, H. D., Jaya, A., \& Limin, S. (2002). The amount of carbon released from peat and forest fires in Indonesia during 1997. Nature, 420(6911), 2930 .

Parresol, B. R. (1999). Assessing tree and stand biomass: a review with examples and critical comparisons. Forest Science, 45, 573-593.

Pilli, R., Anfodillo, T., \& Carrer, M. (2006). Towards a functional and simplified allometry for estimating forest biomass. Forest Ecology and Management, 237(1-3), 583-593.

Posa, M. R. C., Wijedasa, L. S., \& Corlett, R. T. (2011). Biodiversity and Conservation of Tropical Peat Swamp Forests. BioScience, 61(1), 49-57. doi:10.1525/bio.2011.61.1.10

Rieley, J. O. (2007). Tropical peatland -The amazing dual ecosystem: Co-existence and mutual benefit. In J. O. Rieley, C. J. Banks \& B. Radjagukguk (Eds.), Carbon-climate-human interaction on tropical peatland. Proceedings of The International Symposium and Workshop on Tropical 
Peatland, (pp. 339). Yogyakarta, 27-29 August 2007: EU CARBOPEAT and RESTORPEAT Partnership, Gadjah Mada University, Indonesia and University of Leicester, United Kingdom.

Rieley, J. O., \& Page, S. E. (Eds.). (2005). Wise use of tropical peatlands: focus on Southeast Asia: ALTERRA-Wageningen University and Research Centre and the EU INCOSTRAPEAT and RESTORPEAT Partnerships.

Saatchi, S. S., Harris, N. L., Brown, S., Lefsky, M., Mitchard, E. T. A., Salas, W., \& Morel, A. (2011). Benchmark map of forest carbon stocks in tropical regions across three continents. Proceedings of the National Academy of Sciences, Early Edition, 1-6. doi:10.1073/ pnas. 1019576108

Saatchi, S. S., Houghton, R. A., Dos Santos Alvala, R. C., Soares, J. V., \& Yu, Y. (2007). Distribution of aboveground live biomass in the Amazon basin. Global Change Biology, 13(4), 816-837. doi: 10.1111/j.1365-2486.2007.01323.x

Segura, M., \& Kanninen, M. (2005). Allometric Models for Tree Volume and Total Aboveground Biomass in a Tropical Humid Forest in Costa Rica. Biotropica, 37(1), 2-8. doi: 10.1111/j.1744-7429.2005.02027.x

Sierra, C. A., del Valle, J. I., Orrego, S. A., Moreno, F. H., Harmon, M. E., Zapata, M., \& Benjumea, J. F. (2007). Total carbon stocks in a tropical forest landscape of the Porce region, Colombia. Forest Ecology and Management, 243(23), 299-309.

Snowdon, P. (1991). A ratio estimator for bias correction in logarithmic regressions. Canadian Journal of Forest Research, 21, 720-724.

Solichin, Lingenfelder, M., \& Steinmann, K. H. (2011). Tier 3 biomass assessment for baseline emission in Merang peat swamp forest Workshop on Tropical Wetland Ecosystems of Indonesia: Science Needs to Address Climate Change Adaptation and Mitigation, 11-14 April 2011 (pp. 6pp). Sanur Beach Hotel, Bali, Indonesia: US Forest Service, FORDA Ministry of Forestry of Indonesia, CIFOR and USAID.

Sorensen, K. W. (1993). Indonesian peat swamp forests and their role as a carbon sink. Chemosphere, 27(6), 1065-1082.

SPSS Inc. (2005). SPSS Base 14.0 User's Guide. Chicago, IL: SPSS Inc.
Tan, A., Hutabarat, J., \& Tjawikrama, D. (2011). Above ground biomass content on Sungai Putri peatland forest, West Kalimantan-Indonesia Workshop on Tropical Wetland Ecosystems of Indonesia: Science Needs to Address Climate Change Adaptation and Mitigation, 11-14 April 2011 (pp. 6pp). Sanur Beach Hotel, Bali, Indonesia: US Forest Service, FORDA Ministry of Forestry of Indonesia, CIFOR and USAID.

Tawaraya, K., Takaya, Y., Turjaman, M., Tuah, S. J., Limin, S. H., Tamai, Y., \& Osaki, M. (2003). Arbuscular mycorrhizal colonization of tree species grown in peat swamp forests of Central Kalimantan, Indonesia. Forest Ecology and Management, 182(1-3), 381-386.

Ter-Mikaelian, M. T., \& Korzukhin, M. D. (1997). Biomass equations for sixty-five North American tree species. Forest Ecology and Management, 97(1), 1-24.

Uryu, Y., Mott, C., Foead, N., Yulianto, K., Budiman, A., Setiabudi, \& Stuwe, M. (2008). Deforestation, Forest Degradation, Biodiversity Loss and CO2 Emissions in Riau, Sumatra, Indonesia. Jakarta, Indonesia: WWF Indonesia Technical Report.

Verwer, C. C., \& Meer, P. J. v. d. (2010). Carbon pools in tropical peat forest - Toward a reference value for forest biomass carbon in relatively undisturbed peat swamp forests in Southeast Asia (pp. 67pp). Wageningen, The Netherlands: Alterra, Alterra-report 2108.

Wahyunto, Dariah, A., \& Agus, F. (2010). Distribution, Properties, and Carbon Stock of Indonesian Peatland. In Z.-S. Chen \& F. Agus (Eds.), Proceeding of International Workshop on Evaluation and Sustainable Management of Soil Carbon Sequestration in Asian Countries, Bogor, Indonesia, September 28-29, 2010, (pp. 187-204). Bogor, Indonesia: Indonesian Soil Research Institute, Indonesia, Food \& Fertilizer Technology Center, Taiwan and National Institute for Agro-Environmental Sceinces, Japan.

Wahyunto, Heryanto, B., Bekti, H., \& Widiastuti, F. (2006). Peta-peta Sebaran Laban Gambut, Luas dan Kandungan Karbon di Papua/Maps of Peatlands Distribution, Area and Carbon Content in Papua, 2000-2001 (in Indonesian). Bogor, Indonesia: Wetlands International-Indonesia Programme and Wildlife Habitat Canada (WHC). 
Wahyunto, Ritung, S., \& Subagjo, H. (2003). Peta Luas Sebaran Lahan Gambut dan Kandungan Karbon di Pulau Sumatera/Maps of Area of Peatlands Distribution and Carbon Content in Sumatera, 1990-2002 (in Indonesian). Bogor, Indonesia: Wetlands International-Indonesia Programme and Wildlife Habitat Canada (WHC).

Wahyunto, Ritung, S., \& Subagjo, H. (2004). Peta Sebaran Laban Gambut, Luas dan Kandungan Karbon di Pulau Kalimantan/Maps of Peatlands Distribution, Area and Carbon Content in Kalimantan, 2000-2002 (in Indonesian). Bogor, Indonesia: Wetlands International-Indonesia Programme and Wildlife Habitat Canada (WHC).

Wahyunto, Ritung, S., Suparto, \& Subagjo, H. (2005). Sebaran Gambut dan Kandungan Karbon di Sumatera dan Kalimantan. Bogor, Indonesia: Climate Change, Forests and Peatlands in Indonesia Project. Wetlands InternationalIndonesia Programme and Wildlife Habitat Canada.

Wahyunto, \& Suryadiputra, I. N. N. (2008). Peatland Distribution in Sumatra and Kalimantan Explanation of its data sets including source of information, accuracy, data constraints and gaps (pp. 64pp). Bogor, Indonesia: Wetlands International - Indonesia Programme.

Wang, C. (2006). Biomass allometric equations for 10 co-occuring tree species in Chinese temperate forests. Forest Ecology and Management, 222, 9-16.

Wijaya, A., Kusnadi, S., Gloaguen, R., \& Heilmeier, H. (2010). Improved strategy for estimating stem volume and forest biomass using moderate resolution remote sensing data and GIS. Journal of Forestry Research, 21(1), 1-12. doi: 10.1007/s11676-010-0001-7

Wösten, J. H. M., Berg, J. V. D., Van Eijk, P., Gevers, G. J. M., Giesen, W. B. J. T., Hooijer, A., \& Wibisono, I. T. (2006). Interrelationships between Hydrology and Ecology in Fire Degraded Tropical Peat Swamp Forests. International Journal of Water Resources Development, 22(1), 157-174.

Wösten, J. H. M., Clymans, E., Page, S. E., Rieley, J. O., \& Limin, S. H. (2008). Peat-water interrelationships in a tropical peatland ecosystem in Southeast Asia. CATENA, 73(2), 212-224.
Yamakura, T., Hagihara, A., Sukardjo, S., \& Ogawa, H. (1986). Aboveground biomass of tropical rain forest stands in Indonesian Borneo. Plant Ecology, 68(2), 71-82.

Zianis, D. (2008). Predicting mean aboveground forest biomass and its associated variance. Forest Ecology and Management, 256(6), 14001407.

Zianis, D., \& Mencuccini, M. (2004). On simplifying allometric analyses of forest biomass. Forest Ecology and Management, 187(2-3), 311-332.

Zianis, D., Muukkonen, P., Makipaa, R., \& Mencuccini, M. (2005). Biomass and stem volume equations for tree species in Europe: The Finnish Society of Forest Science, The Finnish Forest Research Institute. 
APPENDIX 1. Sampled trees destructively collected to develop site-specific allometric equations for AGB estimation in tropical peat swamp forests

\begin{tabular}{|c|c|c|c|c|}
\hline \multirow{2}{*}{ ID } & \multicolumn{2}{|r|}{ Tree species } & \multirow{2}{*}{$\begin{array}{l}\mathrm{DBH} \\
\text { (cm) }\end{array}$} & \multirow{2}{*}{$\begin{array}{c}H \\
\text { (m) }\end{array}$} \\
\hline & Local name & Scientific name & & \\
\hline 1 & Terentang & Campnosperma coriaceum (Jack.) Hallier f. ex v. Steenis & 9.6 & 10.3 \\
\hline 2 & Terentang & Campnosperma coriaceum (Jack.) Hallier f. ex v. Steenis & 15.1 & 12.4 \\
\hline 3 & Terentang & Campnosperma coriaceum (Jack.) Hallier f. ex v. Steenis & 21.6 & 12.2 \\
\hline 4 & Terentang & Campnosperma coriaceum (Jack.) Hallier f. ex v. Steenis & 31.5 & 23.5 \\
\hline 5 & Terentang & Campnosperma coriaceum (Jack.) Hallier f. ex v. Steenis & 42.6 & 32.1 \\
\hline 6 & Terentang & Campnosperma coriaceum (Jack.) Hallier f. ex v. Steenis & 52.5 & 34.3 \\
\hline 7 & Kelat & Carallia bracbiata (Lour.) Merr. & 8.3 & 10.0 \\
\hline 8 & Jambu-jambu & Eugenia sp.L. & 7.8 & 10.3 \\
\hline 9 & Jambu-jambu & Eugenia sp.L. & 15.5 & 13.8 \\
\hline 10 & Jambu-jambu & Eugenia sp.L. & 22.3 & 19.8 \\
\hline 11 & Jambu-jambu & Eugenia sp.L. & 33.1 & 17.9 \\
\hline 12 & Manggis-manggis & Garcinia celebica (Burm.) L. & 6.0 & 6.9 \\
\hline 13 & Manggis-manggis & Garcinia celebica (Burm.) L. & 18.5 & 17.1 \\
\hline 14 & Manggis-manggis & Garcinia celebica (Burm.) L. & 25.1 & 18.7 \\
\hline 15 & Manggis-manggis & Garcinia celebica (Burm.) L. & 31.2 & 21.5 \\
\hline 16 & Ramin & Gonystylus bancanus (Miq.) Kurz. & 5.2 & 8.1 \\
\hline 17 & Ramin & Gonystylus bancanus (Miq.) Kurz. & 11.8 & 15.5 \\
\hline 18 & Ramin & Gonystylus bancanus (Miq.) Kurz. & 24.8 & 22.4 \\
\hline 19 & Ramin & Gonystylus bancanus (Miq.) Kurz. & 38.3 & 30.7 \\
\hline 20 & Ramin & Gonystylus bancanus (Miq.) Kurz. & 40.0 & 30.2 \\
\hline 21 & Ramin & Gonystylus bancanus (Miq.) Kurz. & 62.7 & 39.4 \\
\hline 22 & Darah-darah & Horsfieldia glabra (Blume) Warb. & 7.1 & 9.3 \\
\hline 23 & Darah-darah & Horsfieldia glabra (Blume) Warb. & 8.5 & 7.5 \\
\hline 24 & Darah-darah & Horsfieldia glabra (Blume) Warb. & 13.6 & 13.8 \\
\hline 25 & Darah-darah & Horsfieldia glabra (Blume) Warb. & 23.6 & 22.5 \\
\hline 26 & Darah-darah & Horsfieldia glabra (Blume) Warb. & 33.0 & 23.9 \\
\hline 27 & Pasir-pasir & Ilex macrophylla Hook. F. & 6.8 & 8.7 \\
\hline 28 & Pasir-pasir & Ilex macrophylla Hook. F. & 10.6 & 12.5 \\
\hline 29 & Pasir-pasir & Ilex macrophylla Hook. F. & 22.0 & 16.6 \\
\hline 30 & Pasir-pasir & Ilex macrophylla Hook. F. & 36.5 & 24.5 \\
\hline 31 & Pasir-pasir & Ilex macrophylla Hook. F. & 40.0 & 24.1 \\
\hline 32 & Pasir-pasir & Ilex macrophylla Hook. F. & 54.4 & 27.9 \\
\hline 33 & Balam & Palaquium obovatum (Griffith) Enql. & 7.6 & 7.8 \\
\hline 34 & Balam & Palaquium obovatum (Griffith) Enql. & 17.0 & 17.2 \\
\hline 35 & Balam & Palaquium obovatum (Griffith) Enql. & 28.5 & 24.8 \\
\hline 36 & Balam & Palaquium obovatum (Griffith) Enql. & 30.3 & 23.2 \\
\hline 37 & Balam & Palaquium obovatum (Griffith) Enql. & 41.0 & 29.1 \\
\hline 38 & Balam & Palaquium obovatum (Griffith) Enql. & 51.5 & 28.1 \\
\hline 39 & Milas & Parastemon urophyllum (Wallich. ex A. DC) A.DC & 7.6 & 11.5 \\
\hline 40 & Milas & Parastemon urophyllum (Wallich. ex A. DC) A.DC & 15.8 & 20.0 \\
\hline 41 & Milas & Parastemon urophyllum (Wallich. ex A. DC) A.DC & 23.1 & 26.4 \\
\hline 42 & Milas & Parastemon urophyllum (Wallich. ex A. DC) A.DC & 32.7 & 28.8 \\
\hline 43 & Milas & Parastemon urophyllum (Wallich. ex A. DC) A.DC & 43.7 & 33.5 \\
\hline 44 & Milas & Parastemon urophyllum (Wallich. ex A. DC) A.DC & 54.5 & 33.2 \\
\hline 45 & Meranti bunga & Shorea teysmanniana Dyer ex Brandis & 9.0 & 9.8 \\
\hline 46 & Meranti batu & Shorea uliginosa Foxw. & 8.5 & 6.4 \\
\hline 47 & Meranti batu & Shorea uliginosa Foxw. & 12.5 & 12.8 \\
\hline 48 & Meranti batu & Shorea uliginosa Foxw. & 22.7 & 25.0 \\
\hline 49 & Meranti batu & Shorea uliginosa Foxw. & 31.0 & 28.8 \\
\hline 50 & Meranti batu & Shorea uliginosa Foxw. & 43.7 & 33.3 \\
\hline 51 & Meranti batu & Shorea uliginosa Foxw. & 50.7 & 33.3 \\
\hline
\end{tabular}


APPENDIX 2. Normal P-P Plot of regression standardized residual and scatterplot of regression standardized predicted value against regression standardized residual for each model: (a) Model 1, (b) Model 2, (c) Model 3, (d) Model 4, and (e) Model 5
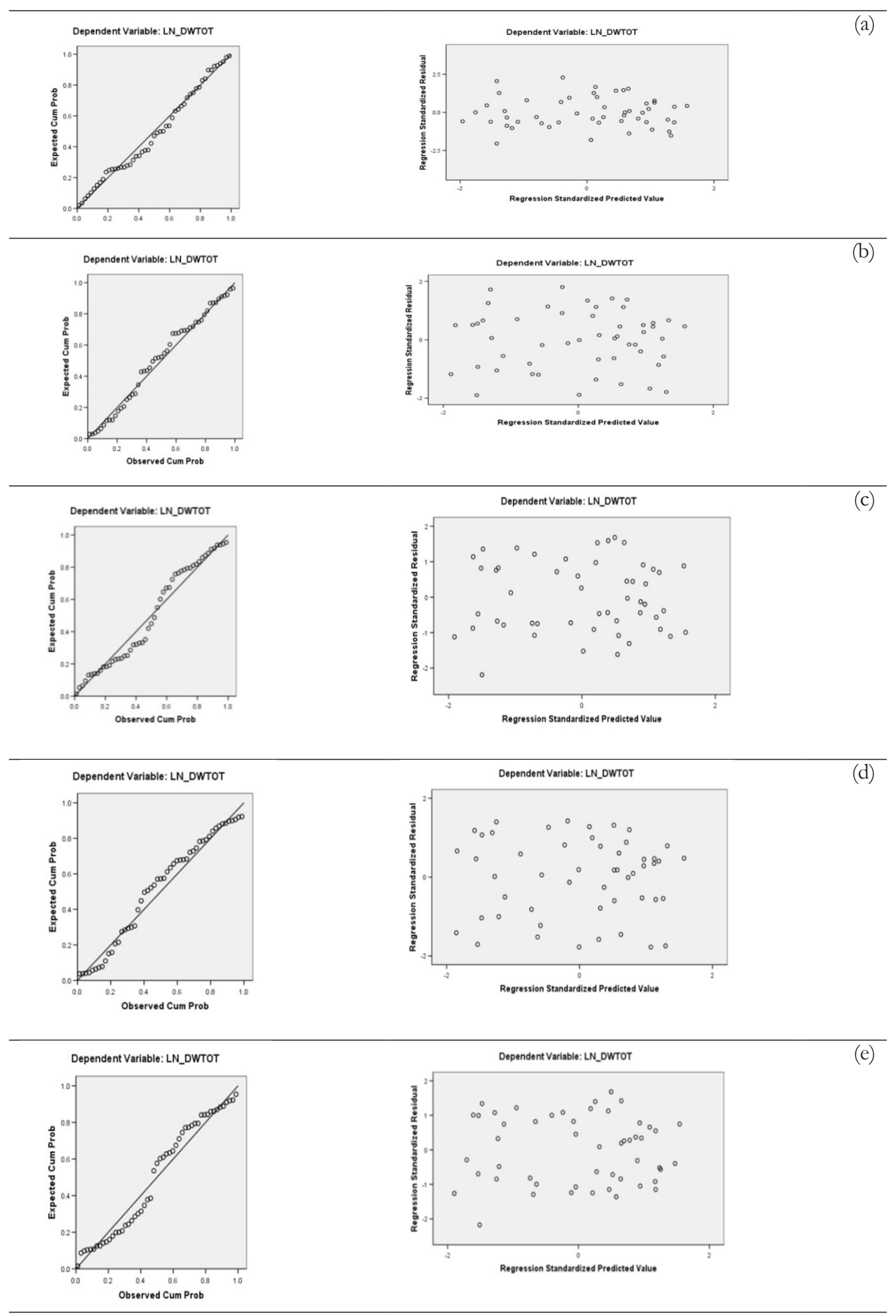
APPENDIX 3. Scatterplots of predicted AGB against observed AGB for each model without correction (left hand side) and with correction using Snowdon's formula (right hand side): (a) Model 1, (b) Model 2, (c) Model 3, (d) Model 4, and (e) Model 5.
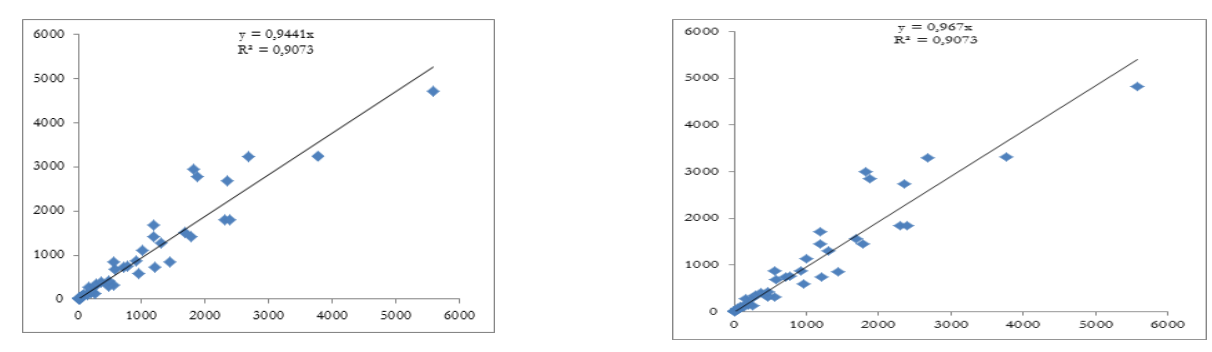

(a)
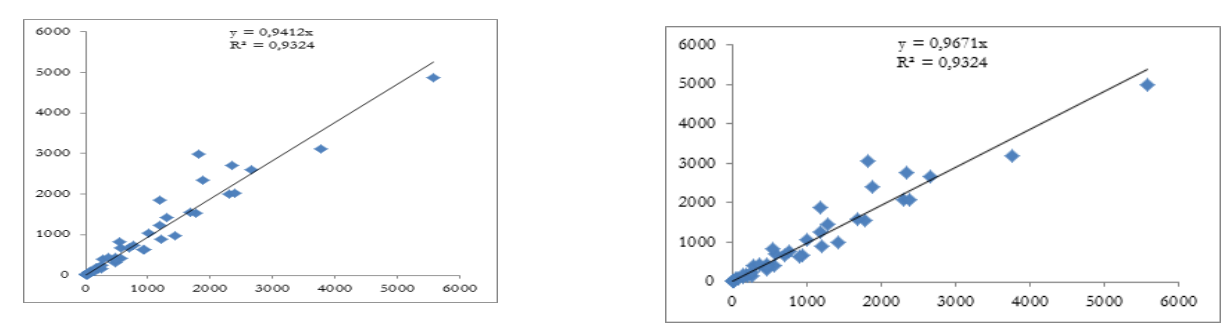

(b)
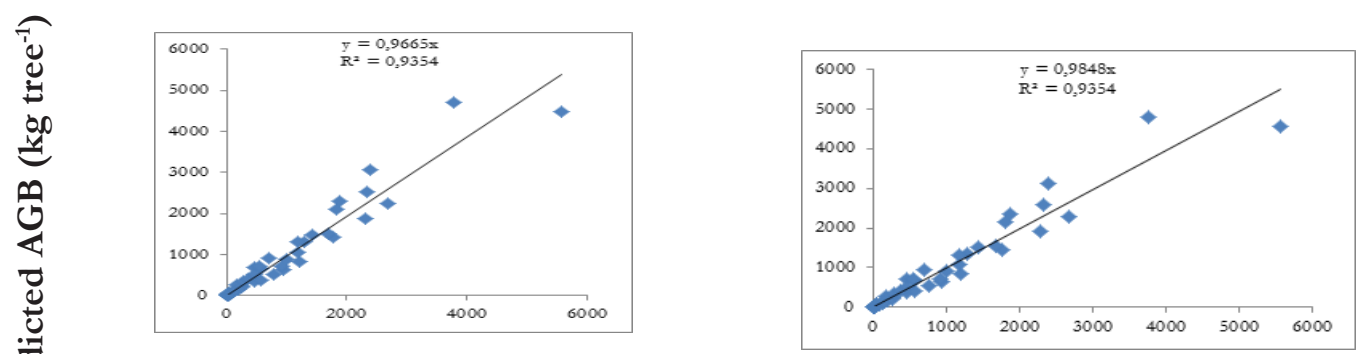

(c)
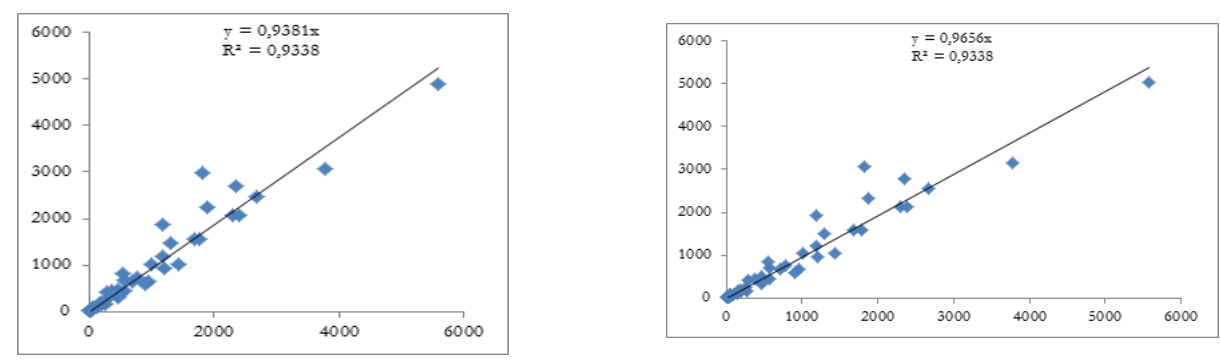

(d)
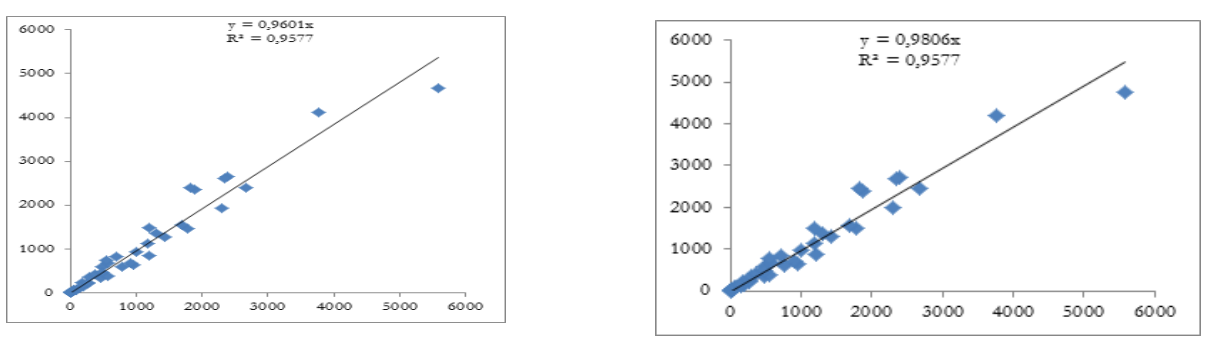

(e)

\section{Observed AGB ( $\mathrm{kg}$ tree $\left.^{-1}\right)$}


Indonesian Journal of Forestry Research Vol. 1, No. 1, April 2014 